\title{
GAMBARAN PERENCANAAN DAN PENGADAAN OBAT DI PUSKESMAS RAWAT JALAN KABUPATEN ROKAN HULU TAHUN 2018
}

\author{
Erniza Pratiwi $^{1 *}$, Septia Roza ${ }^{1}$, Ratna Sari Dewi $^{1}$, Novia Sinata $^{1}$ \\ ${ }^{1}$ Sekolah Tinggi Ilmu Farmasi Riau, Jalan Kamboja Simpang Baru Panam, Telp. (0761)5880007 \\ 1*e-mail:ernizapratiwi@gmail.com
}

\begin{abstract}
ABSTRAK
Telah dilakukan penelitian tentang gambaran perencanaan dan pengadaan obat di puskesmas rawat jalan di Kabupaten Rokan Hulu p ada tahun 2018. Tujuan penelitian ini dilakukan untuk melihat gambaran perencanaan dan pengadaan obat di puskesmas rawat jalan di Kabupaten Rok an Hulu pada tahun 2018 yang mengacu pada Permenkes nomor 74 tahun 2016 serta melihat kesesuaian pelaksanaan perencanaan dan pengad aan di puskesmas rawat jalan yang ada di Kabupaten Rokan Hulu. Jenis penelitian adalah observasional yang bersifat deskriptif kuantitatif deng an pengumpulan data secara restropektif yaitu dari bulan januari sampai desember 2018. Sampel yang digunakan adalah 13 puskesmas rawat jalan dan 80 sampel obat yang ada dalam LPLPO. Hasil penelitiannya adalah berdasarkan elemen penilaian Permenkes nomor 74 tahun 2016, sistem perencanaan ob at puskesmas rawat jalan secara keseluruhan sudah memenuhi persyaratan dengan persentase $97,43 \%$ dengan kategori sangat baik dan sistem pengadaan obat sudah mencapai $100 \%$. Berdasarkan hasil penilaian kesesuaian, kesesuaian perencanaan obat mencapai persentase $90,3 \%$ dan kesesuaian p engadaan obat mencapai persentase $79,90 \%$.
\end{abstract}

Keywords: Pengelolaan obat, perencanaan, pengadaan, puskesmas

\section{ABSTRACT}

A study was conducted on the description of drug planning and procurement at outpatient health centers in Rokan Hulu Regency in 2018. The purpose of this study was to look at the description of drug planning and procurement at outpatient health centers in Rokan Hulu Regency in 2018 referring to Permenkes number 74 years 2016 and see the suitability of the implementation of planning and procurement in outpatient health centers in Rokan Hulu Regency. This type of research is quantitative descriptive observational with a retrospective data collection from January to December 2018. The sample used was 13 outpatient health centers and 80 drug samples in the LPLPO. The results of his research are based on the Permenkes assessment element number 74 of 2016, the overall outpatient puskesmas drug planning system meets the requirements with a percentage of $97.43 \%$ with a very good category and the drug procurement system has reached $100 \%$. Based on the results of conformity assessment, the suitability of drug planning reaches a percentage of $90.3 \%$ and suitability of drug procurement reaches a percentage of $79.90 \%$.

Keywords : Drug management, planning, procurement, puskesmas

\section{PENDAHULUAN}

Upaya Kesehatan adalah setiap kegiatan untuk memelihara dan meningkatkan kesehatan, bertujuan untuk mewujudkan derajat kesehatan yang optimal bagi masyarakat. Puskesmas merupakan fasilitas pelayanan kesehatan dasar yang menyelenggarakan upaya kesehatan pemeliharaan, peningkatan kesehatan (promotif), pencegahan penyakit (preventif), penyembuhan penyakit (kuratif), dan pemulihan kesehatan (rehabilitatif), yang dilaksanakan secara menyeluruh, terpadu, dan berkesinambungan. Konsep kesatuan upaya kesehatan ini menjadi pedoman dan pegangan bagi semua fasilitas pelayanan kesehatan di Indonesia termasuk Puskesmas (Anonima, 2016).

Puskesmas unit pelaksana teknis Dinas Kesehatan Kabupaten atau Kota yang bertanggung jawab menyelenggarakan pembangunan kesehatan disatu atau sebagian wilayah Kecamatan. Pelayanan kesehatan berkaitan dengan pelayanan obat dan pelayanan obat tergantung dari ketersediaan obat di puskesmas (Anonim, 2014).

Salah satu program pokok yang ada di puskesmas adalah program pengobatan. Program pengobatan di puskesmas merupakan bentuk pelayanan kesehatan dasar yang bersifat kuratif. Masyarakat memanfaatkan pelayanan puskesmas hanya untuk mendapatkan pelayanan pengobatan, oleh karena itu obat harus tersedia di puskesmas setiap waktu dan untuk menjamin ketersediaan obat maka perlu perencanaan yang baik di puskesmas (Muninjaya, 2004).

Obat merupakan komponen esensial dari pelayanan kesehatan oleh sebab itu diperlukan suatu sistem manajemen yang baik dan berkesinambungan. Dalam pelayanan kesehatan obat merupakan salah satu alat yang tidak dapat tergantikan, dengan demikian penyediaan obat esensial merupakan kewajiban bagi pemerintah dan institusi pelayanan kesehatan publik maupun swasta, karena kekurangan obat di sarana kesehatan dapat berdampak pada menurunnya kepercayaan masyarakat terhadap institusi kesehatan serta dapat menurunkan semangat kerja staf pelayanan kesehatan (Rismalawati dkk, 2015).

Ketidakcukupan obat-obatan disebabkan oleh berbagai faktor. Salah satu faktor yang sangat menentukan yaitu faktor perencanaan/hperhitungan perkiraan kebutuhan obat. Pengadaan obat juga merupakan suatu aspek dimana permintaan dilakukan harus sesuai dengan kebutuhan obat agar tidak terjadi kelebihan atau kekurangan obat. Terjaminnya 
ketersediaan obat di pelayanan kesehatan akan menjaga citra pelayanan kesehatan itu sendiri, sehingga pengelolaan dan penyediaan obat secara efektif dan efisien sangatlah penting.

Berdasarkan penelitian yang dilakukan Indriawan dkk (2014) di Puskesmas Gaya Baru V Kecamatan Bandar Surabaya Kabupaten Lampung Tengah, dimana tahap perencanaan kebutuhan obat di puskesmas ini menggunakan metode konsumsi dan metode epidemiologi tetapi pada tahap pemilihan obat belum menggunakan tahap seleksi ilmiah medik dan statistik, karena kurangnya tenaga yang ada. Berdasarkan dari hasil penelitian itu maka perencanaan obat di Instalasi Gudang Obat Puskesmas Gaya Baru V belum sepenuhnya memenuhi tahap tahap atau metode yang sesuai dengan perencanaan obat.

Prosedur dan cara pengadaan obat di Puskesmas Gaya Baru V sudah sesuai dengan Pedoman Pengelolaan Obat Publik dan perbekalan Kesehatan di Puskesmas, yaitu membuat permintaan obat rutin setiap tiga bulan sekali dan permintaan khusus dilakukan sewaktu waktu.

Berdasarkan penelitian yang dilakukan Husnawati dkk (2016) di Puskesmas Rambah Samo I dan Puskesmas Rambah Samo II di Kabupaten Rokan Hulu dimana dari hasil penelitian tentang perencanaan obat di Puskesmas Kecamatan Rambah Samo yaitu Puskesmas Rambah Samo I sudah sangat baik dengan persentase angka $100 \%$ karna sistem perencanaan obat di Puskesmas Rambah Samo I sudah melakukan alur perencanaan obat yaitu dimulai dengan proses perencanaan kebutuhan obat di puskesmas per tahun dilakukan secara berjenjang, kemudian perencanaan obat di puskesmas setiap periode dilakukan oleh petugas farmasi. Berbeda dengan Puskesmas Rambah Samo II dimana persentase angka 75\% dengan kriteria baik, karena terdapat beberapa alur perencanaan obat yang belum dilaksanakan oleh Puskesmas Rambah Samo II yaitu proses perencanaan kebutuhan obat di puskesmas setiap periode belum dilaksanakan oleh petugas farmasi. Hal ini disebabkan karena keterbatasan jumlah tenaga farmasi yang ada di puskesmas tersebut.

Penelitian tentang pengelolaan juga dilakukan oleh Mangindara dkk (2012) di Puskesmas Kampala Kecamatan Sinjai Timur Kabupaten Sinjai dimana sudah memenuhi standar perencanaan dan pengadaan obat di puskesmas. Metode perencanaan obat yang dipilih di Puskesmas Kampala Kecamatan Sinjai Timur Kabupaten Sinjai yaitu dengan metode konsumsi, dimana perencanaan obat dilakukan Puskesmas Kampala mengacu pada kebutuhan obat sebelumnya.

Pengadaan obat di Puskesmas Kampala berdasarkan kebutuhan dan pola penyakit dengan menggunakan Laporan Pemakaian dan Lembar Permintaan Obat yang disampaikan ke Dinas Kesehatan Kabupaten/Kota setiap triwulan. Penelitian serupa juga dilakukan oleh Rahma (2018) di Puskesmas "X" di Kota Surabaya, dimana proses perencanaan dan pengadaan obat sudah sesuai dengan Permenkes Nomor 74 Tahun 2016, akan tetapi masih terdapat beberapa kendala yang ditemukan dalam pengadaan obat. Beberapa kendala yang ditemukan diantaranya yaitu: Pertama, kegiatan pengadaan menbutuhkan waktu yang lama sehingga berpengaruh terhadap pemberian pelayanan di puskesmas. Kedua, Puskesmas tidak bisa melakukan kegiatan pengadaan diluar periode pengadaan obat yang sudah ditentukan kecuali dalam keadaan darurat seperti Kejadian Luar Biasa (KLB), Bencana Alam, dan sebagainya.

Penelitian yang sama dilakukan oleh Aprilliani dkk (2018) yang dilakukan di Puskesmas Karanganyar I dimana pengelolaan obat pada tahap perencanaan berdasarkan penggunaan indikator perencanaan menunjukkan efektif dengan rata-rata $20 \%$ efektif, karena masih terdapat sisa stok yang tersedia untuk waktu tunggu dan stok pengaman diharapkan tidak terjadi kekosongan obat, tetapi pada tingkat ketersediaan obat kurang aman dikarenakan terlalu banyak jenis obat yang dapat menimbulkan pembengkakan dana Anggaran Pendapatan dan Belanja Daerah (APBD), Dinas Kesehatan memberikan obat yang tidak sesuai dengan permintaan terkadang bisa lebih atau kurang tergantung stok di Gudang Farmasi Kabupaten/Kota.

Berdasarkan hasil pemaparan diatas, peneliti

merasa tertarik untuk melakukan penelitian mengenai Gambaran Perencanaan dan Pengadaan Obat di Puskesmas Rawat Jalan yang ada di Kabupaten Rokan Hulu, dimana di Kabupaten Rokan Hulu terdapat 21 Puskesmas yang terdiri atas 13 Puskesmas non rawatan/rawat jalan dan 8 Puskesmas rawatan/rawat inap. Bila dilihat dari letak geografis wilayah Kabupaten Rokan Hulu dimana puskesmas rawat jalan sebagian besar berada di wilayah yang jauh dari Rumah Sakit Umum Daerah (RSUD) maka sangat besar harapan masyarakat kepada puskesmas untuk dapat menjamin ketersediaan obat di wilayah tersebut sehingga pelayanan kesehatan terutama pengobatan kepada masyarakat tetap terjamin sehingga tercapai derajat kesehatan yang setinggi-tingginya. Peneliti ingin melihat bagaimana gambaran perencana dan pengadaan obat di puskesmas non rawatan/rawat jalan sehingga dapat menjamin ketersediaan obat di puskesmas.

\section{METODOLOGI PENELITIAN}

Penelitian ini dilaksanakan di Puskesmas Rawat Jalan Kabupaten Rokan Hulu dan Instalasi Farmasi 
Kabupaten Rokan Hulu. Penelitian ini merupakan penelitian observasional yang bersifat deskriptif kuantitatif dengan pengumpulan data secara retrospektif yaitu dengan cara pengumpulan data yang telah lalu pada tahun 2018. Sampel pada penelitian ini adalah 13 Puskesmas rawat jalan di Kabupaten Rokan Hulu dan 80 sampel obat yang ada di Rencana Kebutuhan Obat (RKO) dan Lembar Permintaan dan Laporan Pemakaian Obat (LPLPO) dari 13 Puskesmas rawat jalan. Penentuan sampel obat menggunakan teknik simple random sampling (acak sederhana) adalah cara pengambilan sampel yang dilakukan secara acak sehingga setiap kasus atau elemen dalam populasi memiliki kesempatan yang sama besar untuk dipilih sebagai sampel penelitian dan sampling error dapat ditentukan (Supardi dan Surahman, 2014).

\section{HASIL DAN PEMBAHASAN}

Setelah dilakukan penelitan di Instalasi Farmasi dan Puskesmas Rawat Jalan yang berada di Kabupaten Rokan Hulu untuk melihat bagaimana gambaran perencanaan dan pengadaan obat di Puskesmas rawat jalan yang berada di Kabupaten Rokan Hulu pada tahun

2018 diperoleh hasil sebagai berikut:

A. Sistem Perencanaan dan pengadaan Obat Puskesmas

1. Hasil Penilaian Sistem Perencanaan Obat Puskesmas

Tabel 1. Hasil Persentase Perencanaan dan Pengadaan Obat

\begin{tabular}{|c|c|c|c|}
\hline No & Elem & Pers yaratan & Persentase \\
\hline \multicolumn{4}{|c|}{ Perencanaan } \\
\hline 1 & A & $\begin{array}{l}\text { Perencanaan kebutuhan } \\
\text { obat dilaksanakan oleh } \\
\text { Proses seleksi dilakukan } \\
\text { dengan mempertimbang kan }\end{array}$ & 100 \\
\hline 2 & B & $\begin{array}{l}\text { diantaranya yaitu pola } \\
\text { konsumsi periode sebelumnya, } \\
\text { Proses seleksi sediaan farmasi } \\
\text { dan bahan medis habis pakai }\end{array}$ & 97,43 \\
\hline 3 & $\mathrm{C}$ & $\begin{array}{l}\text { Esensial (DOEN) dan } \\
\text { Formularium }\end{array}$ & 100 \\
\hline \multicolumn{4}{|c|}{ Pengadaan } \\
\hline & & Permintaan sediaan farmasi & \\
\hline 4 & & $\begin{array}{l}\text { dan BMHP diajukan pada } \\
\text { kepala Dinas Kesehatan }\end{array}$ & 100 \\
\hline
\end{tabular}

Terdapat 3 elemen persyaratan perencanaan (elemen A, elemen B, elemen C) dan 1 persyaratan pengadaan obat berdasarkan permenkes Nomor 74 tahun 2016. Berdasarkan pedoman untuk elemen A yaitu pelaksanaan perencanaan kebutuhan obat dilaksanakan diruang farmasi puskesmas secara rutin. Hasil penelitian yang diperoleh dimana pada lembaran check list perencanaan elemen A mendapat skor $100 \%$, dapat dikatakan secara keseluruhan semua puskesmas rawat jalan sudah melaksanakan perencanaan diruang farmasi dengan sangat baik dimana ditemukan data laporan RKO selama 3 tahun terakhir yang sudah ditanda tangani tenaga kefarmasian atau penanggung jawab bagian farmasi di puskesmas.

Berdasarkan pedoman untuk elemen B dimana mengamati proses seleksi dilakukan dengan mempertimbangkan diantaranya yaitu pola konsumsi periode sebelumnya, pola penyakit, data mutasi sediaan farmasi dan rencana pengembangan. Pada persyaratan perencanaan yang berdasarkan elemen B didapat hasil 92,3\% dengan parameter pengukurannya jika ditemukan data LPLPO selama 1 tahun yaitu sebanyak 12 laporan. Laporan Pemakaian dan Lembar Permintaan Obat (LPLPO) merupakan suatu format yang digunakan oleh puskesmas untuk melaporkan keadaan obat dan pengajuan permintaan obat, selain itu LPLPO diharapkan dapat menyediakan data yang cukup dan benar yang diperlukan kapan saja oleh unit diatasnya untuk melaksanakan fungsi-fungsi pengelolaan obat dnegan baik serta pengaturan dan pengendalian terhadap unit dibawahnya.

Pada elemen B ini ditemukan ada satu puskesmas yang tidak memenuhi persyaratan ini disebabkan karena keterlambatan dalam pengiriman laporan ke Dinas Kesehatan Kabupaten Rokan Hulu. Apabila keterlambatan ini terjadi secara berkelanjutan maka akan menimbulkan kendala dalam perencanaan kebutuhan obat di puskesmas tersebut ke Dinas Kesehatan Kabupaten Rokan Hulu yang berdampak pada kebutuhan obat tidak maksimal, didukung dengan kurangnya tenaga kefarmasian di puskemas tersebut yang hanya memiliki 1 orang tenaga kefarmasian, serta tidak adanya apoteker. Dari hasil wawancara dengan tenaga kefarmasian di puskesmas 13 ternyata keterlambatan pengiriman LPLPO ke Dinas Kesehatan Kabupaten Rokan Hulu disebabkan karena adanya mutasi tenaga kefarmasian ke puskesmas lain sehingga terjadi kekosongan tenaga kefarmasian di puskesmas 13 tersebut.

Berdasarkan pedoman untuk elemen $\mathrm{C}$ yaitu proses seleksi sediaan farmasi dan bahan medis habis pakai mengacu pada Daftar Obat Esensial Nasional (DOEN) dan formularium nasional. Pada persyaratan perencanaan yang berdasarkan elemen $\mathrm{C}$ didapat hasil $100 \%$ dimana secara keseluruhan semua puskesmas telah melaksanakan perencanaan obat dengan mengacu kepada Daftar Obat Esensial Nasional (DOEN) dan formulariun nasional, dengan ditemukannya daftar obat di dalam LPLPO sudah sesuai dengan formularium nasional. 
Berdasarkan penelitian yang dilakukan oleh Husnawati dkk (2016) dimana kegiatan perencanaan obat di puskesmas Rambah Samo I diperoleh hasil dengan persentase $100 \%$ dengan intervensi sangat baik. Hal ini sejalan dengan hasil penelitian yang didapatkan pada puskesmas 4 (Rambah Samo I) di kabupaten rokan hulu, didapatkan hasil 100\% dengan kategori sangat baik, dimana ditemukan data LPLPO sebanyak 12 laporan/ tahun di Puskesmas 4 tersebut.

Berdasarkan pedoman untuk elemen persyaratan pengadaan obat yaitu dengan melihat adanya data permintaan sediaan farmasi dan bahan medis habis pakai yang diajukan ke Dinas Kesehatan Kabupaten/ Kota. Pada lembaran check list pengadaan dimana elemen persyaratan permintaan sediaan farmasi dan bahan medis habis pakai diajukan kepada Dinas Kesehatan Kabupaten dengan parameter jika ditemukan laporan permintaan obat tiap 3 bulan ke Dinas Kesehatan Kabupaten Rokan Hulu yaitu LPLPO pada tahun 2018 dan didapat hasil 100\% dengan demikian pengadaan obat di puskesmas rawat jalan di Kabupaten Rokan Hulu telah memenuhi syarat sesuai Permenkes Nomor 74 tahun 2016. Dari hasil lembar check list yang didapat dan data yang diperoleh diukur dengan skala Guttman, perencanaan dan pengadaan obat di puskesmas rawat jalan Kabupaten Rokan Hulu dapat digolongkan pada kriteria sangat baik, dimana sistem perencanaaan obat di puskesmas diperoleh hasil $97,43 \%$ dan pengadaan obat di puskesmas diperoleh hasil 100\%.

Hal ini sejalan dengan penelitian yang dilakukan oleh Rahmah (2016) tentang Perencanaan dan pengadaan obat di Puskesmas X berdasarkan Permenkes nomor 74 tahun 2016, menunjukkan hasil bahwa pelaksanaan perencanaan dan pengadaan obat di Puskesmas " $\mathrm{X}$ " sudah sesuai dengan Permenkes Nomor 74 tahun 2016, dimana hasil observasi kegiatan perencanaan kebutuhan dilakukan dengan membuat Laporan Kebutuhan Obat (LKO)/tahun, kegiatan perencanaan dilakukan secara periodik berdasarkan pemakaian obat periode sebelumnya yang telah direkap dan dihitung, serta perencanaan mengacu pada DOEN dan formularium nasional.

\section{B. Kesesuaian Pelaksanaan Perencanaan} dan Pengadaan Obat di Puskesmas

1. Data Kesesuaian Pelaksanaan Perencanaan Obat di Puskesmas tahun 2018

Pada lembar pengumpulan data, peneliti menilai kesesuaian pelaksanaan kegiatan perencanaan obat di puskesmas dan kesesuaian pengadaan obat di puskesmas. Penilaian terhadap kesesuaian perencanaan obat di puskesmas yaitu melihat kesesuaian antara RKO dengan LPLPO selama satu tahun yaitu pada tahun 2018. Pengambilan data ini dimulai dengan menentukan 80 sampel obat/puskesmas yang akan diteliti, dimana total puskesmas yang diteliti adalah sebanyak 13 puskesmas rawat jalan di Kabupaten Rokan Hulu pada tahun 2018. Dari hasil perhitungan maka ditemukan $90,3 \%$ pelaksanaan permintaan obat sudah sesuai dengan RKO dan 9,7\% belum sesuai antara permintaan dan RKO.

Tabel 2. Hasil Penilaian Kesesuaian Pelaksanaan Perencanaan Obat di Puskesmas Tahun 2018 dengan membandingkan antara data RKO puskesmas dengan data LPLPO tahun 2018

\begin{tabular}{|c|c|c|c|c|c|}
\hline No & Puskesmas & Sesuai & $\begin{array}{l}\text { Tidak } \\
\text { sesuai }\end{array}$ & $\begin{array}{l}\text { Persentase } \\
\text { Kesesuaian }\end{array}$ & $\begin{array}{c}\text { Persentase } \\
\text { Ketidaksesuaian }\end{array}$ \\
\hline 1 & P 1 & 73 & 7 & 91,25 & 8,75 \\
\hline 2 & P 2 & 73 & 7 & 91,25 & 8,75 \\
\hline 3 & P 3 & 75 & 5 & 93,75 & 6,25 \\
\hline 4 & P 4 & 74 & 6 & 92,5 & 7,50 \\
\hline 5 & P 5 & 67 & 13 & 83,75 & 16,25 \\
\hline 6 & P 6 & 64 & 16 & 80,00 & 20,00 \\
\hline 7 & P 7 & 74 & 6 & 92,50 & 7,50 \\
\hline 8 & P 8 & 75 & 5 & 93,75 & 6,25 \\
\hline 9 & P 9 & 72 & 8 & 90,00 & 10,00 \\
\hline 10 & P 10 & 76 & 4 & 95,00 & 5,00 \\
\hline 11 & P 11 & 74 & 6 & 92,50 & 7,50 \\
\hline 12 & P 12 & 69 & 11 & 86,25 & 13,75 \\
\hline 13 & P 13 & 73 & 7 & 91,20 & 8,75 \\
\hline & Total & 939 & 101 & 1173,75 & 126,25 \\
\hline \multicolumn{4}{|c|}{$\begin{array}{c}\text { Rata-rata Persentase }= \\
\text { Total Pers entase } / 13\end{array}$} & 90,3 & 9,7 \\
\hline
\end{tabular}

2. Data Kesesuaian Pelaksanaan Pengadaan Obat di Puskesmas tahun 2018

Tabel 3. Hasil Penilaian Kesesuaian Pelaksanaan Pengadaan Obat di Puskesmas Tahun 2018

\begin{tabular}{|c|c|c|c|c|c|}
\hline Jo & Puskesmas & Sesuai & $\begin{array}{l}\text { Tidak } \\
\text { sesuai }\end{array}$ & $\begin{array}{c}\text { Persentase } \\
\text { Kes esuaian }\end{array}$ & $\begin{array}{c}\text { Persentase } \\
\text { Ketidaksesuaia }\end{array}$ \\
\hline$\overline{1}$ & P 1 & 57 & 23 & 71,25 & 28,75 \\
\hline 2 & P 2 & 58 & 22 & 72,5 & 27,5 \\
\hline 3 & P 3 & 68 & 12 & 85 & 15 \\
\hline 4 & P 4 & 69 & 11 & 86,25 & 13,75 \\
\hline 5 & P 5 & 66 & 14 & 82,5 & 17,5 \\
\hline 6 & P 6 & 57 & 23 & 71,25 & 28,75 \\
\hline 7 & P 7 & 63 & 17 & 78,75 & 21,25 \\
\hline 8 & P 8 & 69 & 11 & 86,25 & 13,75 \\
\hline 9 & P 9 & 68 & 12 & 85 & 15 \\
\hline 10 & P 10 & 69 & 11 & 86,25 & 13,75 \\
\hline$\lfloor 1$ & P 11 & 61 & 19 & 76,25 & 23,75 \\
\hline 12 & P 12 & 67 & 13 & 83,75 & 16,25 \\
\hline \multirow[t]{3}{*}{13} & P 13 & 59 & 21 & 73,75 & 26,25 \\
\hline & Total & 831 & 209 & 1038,75 & 261,25 \\
\hline & $\begin{array}{r}\text { Rata-rata Per } \\
\text { Perser }\end{array}$ & $\begin{array}{l}\operatorname{tase}=1 \\
\mathrm{e} / 13\end{array}$ & & 79,9 & 20,09 \\
\hline
\end{tabular}

Perencanaan obat dikatakan tidak sesuai apabila jumlah obat didalam RKO tahun 2018 tidak sama dengan jumlah permintaan obat puskesmas selama tahun 2018. Penyebab ketidaksesuaian ini dikarenakan dua hal yaitu pertama apabila jumlah permintaan obat kurang dari data awal yang ada di RKO biasanya 
dikarenakan jumlah kasus penyakit berkurang atau dokter penulis resep pindah tugas sehingga obat jarang diresepkan atau tidak pernah diresepkan lagi, kedua apabila jumlah permintaan obat lebih dari RKO biasanya jumlah kasus penyakit yang memakai obat tersebut meningkat Persentase ketidaksesuaian paling tinggi dijumpai di puskesmas 6 dimana persentase ketidak- sesuaian $20 \%$, obat yang tidak sesuai itu diantaranya adalah Risperidone $1 \mathrm{mg}$ dimana perencanaan pada data RKO 0 sedangkan pada data LPLPO terdapat 500 tablet, hal ini dikarenakan adanya pasien rujukan dari Rumah Sakit Jiwa yang mengambil obat rutin dipuskesmas tersebut dan kunjungan pasien ditemukan pada pertengahan tahun 2018. Selain itu untuk perencanaan obat Serum ABU polivalen injeksi pada data RKO 0, sedangkan pada data LPLPO ditemukan permintaan sebanyak 10 vial. Hal ini disebabkan tidak adanya perencanaan serum ABU pada tahun 2017 sehingga menjadi acuan puskesmas untuk perencanaan pada tahun 2018, namun dikarenakan adanya temuan kasus pasien digigit ular, sehingga puskesmas melakukan permintaan ke Dinas Kesehatan Kabupaten Rokan Hulu.

Kegiatan perencanaan kebutuhan obat ini menjadi dasar dari implementasi pengelolaan obat di puskesmas. Perencanaan kebutuhan obat yang tepat akan menghasilkan jumlah dan jenis obat yang tepat sesuai dengan kebutuhan, mencegah terjadinya kekosongan stok obat, meningkatkan penggunaan obat secara rasional, dan meningkatkan efisiensi penggunaan obat (aditama, 2003).

Penilaian terhadap kesesuaian pengadaan obat di puskesmas yaitu melihat kesesuaian antara data permintaan Obat yang ada dalam Laporan Pemakaian dan Lembar Permintaan Obat (LPLPO) dengan Berita Acara Penyerahan (BAP) obat di puskesmas selama satu tahun yaitu pada tahun 2018. Pengambilan data ini dimulai dengan menentukan 80 sampel obat puskesmas yang akan diteliti, dimana total puskesmas yang diteliti adalah sebanyak 13 puskesmas rawat jalan di Kabupaten Rokan Hulu pada tahun 2018. Dari hasil perhitungan maka ditemukan $79,90 \%$ sudah sesuai pelaksanaan permintaan obat dengan membandingkan antara Laporan Pemakaian dan lembar Permintaan Obat (LPLPO) dengan Berita Acara Penyerahan (BAP) Obat dan 20,09\% belum sesuai antara Laporan Pemakaian dan lembar Permintaan Obat (LPLPO) dengan Berita Acara Penyerahan (BAP) Obat .

Pengadaan obat dikatakan tidak sesuai apabila jumlah permintaan yang ada di Laporan Pemakaian dan Lembar Permintaan Obat (LPLPO) tidak sesuai dengan pengadaan dari Dinas Kesehatan Kabupaten Rokan Hulu dengan melihat data Berita Acara Penyerahan (BAP) obat selama tahun 2018. Ketidaksesuaian itu dapat disebabkan oleh beberapa faktor. Faktor penyebab ketidaksesuaian diantaranya faktor ketidaktepatan dalam mengkalkulasikan jumlah sediaan obat seperti stok obat masih banyak yang dapat dilihat dari laporan stok akhir puskesmas datanya ada di Laporan Pemakaian dan Lembar Permintaan Obat (LPLPO) bulan sebelumnya tetapi puskesmas membuat permintaan ke Dinas kesehatan Kabupaten Rokan Hulu sehingga bagian Instalasi Farmasi Dinas Kesehatan kabupaten Rokan Hulu tidak memberikan sejumlah yang diminta, selain itu faktor jumlah sediaan obat di Instalasi Farmasi Kabupaten Rokan Hulu juga dapat menjadi penyebabketidaksesuaian antara perencanaan dan pengadaan di puskesmas seperti jumlah obat yang tersedia tidak cukup sehingga tidak bisa memenuhi kebutuhan dari puskesmas selain itu adanya obat yang hampir mendekati tanggal kadaluarsa sehingga Instalasi Farmasi memberikan dalam jumlah yang besar atau tanpa ada permintaan dari puskesmas. Hal ini sejalan dengan penelitian yang dilakukan oleh Athijah dkk (2010) tentang "Perencanaan dan Pengadaan obat di Puskesmas Surabaya Timur dan Selatan" dimana penerimaan obat tidak selalu sama dengan permintaan.

Faktor lain yang dapat mempengaruhi kesesuaian pengadaan adalah jumlah obat program dari Dinas Kesehatan Provinsi dimana obat yang datang akan dibagi ke seluruh puskesmas sesuai jumlah sasaran penduduk atau adanya kasus penyakit. Selain itu faktor defisit anggaran juga menjadi penyebab ketidaksesuaian pengadaan dimana obat diberikan sesuai anggaran yang ada sehingga tidak semua permintaan puskesmas bisa tercukupi. Persentase ketidaksesuaian paling tinggi ada di dua puskesmas yaitu di puskesmas 1 dan di puskesmas 6 dengan persentase ketidaksesuaian

$28,75 \%$. Adapun contoh obat yang paling terlihat ketidaksesuaian perencanaan yaitu pada obat Amlodipin tablet $5 \mathrm{mg}$, dalam permintaan LPLPO puskesmas sebanyak 1500 tablet tetapi obat yang datang dari Instalasi Farmasi sebanyak 0 tablet. Setelah dilakukan wawancara di puskesmas 6, diperoleh informasi bahwa untuk Amlodipin tablet $5 \mathrm{mg}$ memang kosong di Instalasi Farmasi dan dipakai sebagai obat pengganti adalah Captopril 12,5 mg. Akibat dari penggantian sediaan Amlodipin $5 \mathrm{mg}$ menjadi Captopril 12,5 mg mengakibatkan terjadinya ketidaksesuaian perencanaan dan pengadaan obat untuk captopril 12,5 mg. Meskipun berbeda dalam hal cara kerja obat dimana Amlodipin adalah sejenis obat calcium channel blockers yang bekerja dengan cara melemaskan dinding pembuluh darah dan melebarkan diameter pembuluh darah. Hal ini akan membantu memperlancar aliran darah menuju jantung dan mengurangi tekanan darah dalam pembuluh. Sementara itu, Captopril adalah sejenis obat angiotensin-converting enzyme (ACE) inhibitor yang bekerja dengan cara menghambat produksi hormone angiotensin 2. Hal ini akan membuat pembuluh darah 
lebih rilek sehingga dapat menurunkan tekanan darah sekaligus meningkatkan suplai darah dan oksigen ke jantung. Perbedaan cara kerja tetapi sama - sama membuat pembuluh darah lebih rilek, hal itu yang menjadi pertimbangan dokter untuk menggantinya. Selain itu Metronidazol tablet 250 mg juga menjadi perhatian dimana di data LPLPO terdapat 0 tetapi yang datang dari Instalasi Farmasi sebanyak 500 tablet dikarenakan puskesmas membuat permintaan Metronidazol tablet $250 \mathrm{mg}$ ke Instalasi Farmasi Kabupaten dengan dasar permintaan dari dokter. Banyaknya kasus infeksi saluran kencing yang terdeteksi melalui program Dinas Kesehatan Kabupaten yang dilaksanakan disemester dua tahun 2018 yaitu pemeriksaan rutin IVA dan sadari membuat penanggung jawab kefarmasian merasa perlu meminta ke Instalasi Farmasi Kabupaten meskipun di data RKO tidak ada. Pengadaan obat merupakan suatu proses pemenuhan kebutuhan operasional obat dan bahan medis habis pakai yang dibutuhkan oleh puskesmas, sebagai bentuk realisasi dari perencanaan kebutuhan obat yang telah dilakukan sebelumnya. Hal ini dilakukan untuk menjamin ketersediaan obat dalam jumlah yang tepat diwaktu yang tepat pula (Hadidah, 2016). Dalam hal ini, ketidak tepatan perencanaan obat yang dilakukan sebelumnya akan mempengaruhi proses pengadaan obat yang dilakukan puskesmas. Kedua proses tersebut saling berhubungan dan menentukan ketersediaan obat dan bahan medis habis pakai di puskesmas dalam pemberian pelayanan kesehatan kepada pasien.

\section{SIMPULAN}

Setelah dilakukan penelitian tentang gambaran perencanaan dan pengadaan obat di puskesmas rawat jalan di Kabupaten Rokan Hulu dengan menggunakan lembar check list didapat hasil sebagai berikut: berdasarkan elemen penilaian Permenkes Nomor 74 tahun 2016, sistem perencanaan puskesmas rawat jalan secara keseluruhan sudah memenuhi persyaratan dengan persentase $97,43 \%$ dan masuk dalam kategori sangat baik. Hasil penilaian terhadap sistem pengadaan obat di puskesmas sudah memenuhi persyaratan dengan persentase $100 \%$ dan masuk dalam kategori sangat baik. Berdasarkan hasil penilaian kesesuaian pelaksanaan perencanaan dan pengadaan obat di puskesmas pada tahun 2018 didapatkan hasil sebagai berikut: kesesuaian perencanaan obat sudah mencapai persentase $90,3 \%$ dan kesesuaian pengadaan obat di puskesmas hanya mencapai persentase $79,90 \%$.

\section{SARAN}

Disarankan kepada pihak puskesmas dalam pembuatan perencanaan obat lebih memperhatikan sisa stok obat sebelumnya sehingga tidak terjadi penumpukan obat atau kekosongan stok obat dan disarankan untuk
Instalasi Farmasi lebih memperhatikan lamanya waktu kadaluarsa obat pada saat pengadaan obat.

\section{DAFTAR PUSTAKA}

Aditama, T. 2003. Manajemen Administrasi Rumah Sakit. Jakarta: Universitas Indonesia Press.

Anonim. 2000. Permenkes RI Nomor 949/Menkes/Per/VI/2000. Jakarta: Menteri Kesehatan Republik Indonesia.

Anonim. 2008. Pedoman TeknisPengadaan Obat Publik dan Perbekalan Kesehatan Untuk Pelayanan Kesehatan Dasar. Jakarta: Departemen Kesehatan Republik Indonesia.

Anonim. 2014. Peraturan Menteri Kesehatan Nomor 75 Tahun 2014 Tentang Puskesmas. Jakarta: Departemen Kesehatan.

Anonima. 2016. Peraturan Menteri Kesehatan Nomor 74 Tahun 2016 Tentang Standar Pelayanan Kefarmasian di Puskesmas. Jakarta: Departemen Kesehatan.


Pangaraian: Dinas Kesehatan Rokan Hulu.

Anonim. 2018. Peraturan Badan Pengawasan Obat dan Makanan nomor 4 tahun 2018 tentang Pengawasan pengelolaan obat, bahan obat, narkotika, psikotropika dan prekursor farmasi di fasilitas pelayanan kefarmasian. Jakarta: BPOM RI

Aprilliani, R. P. C. 2018. Evaluasi Pengelolaan Obat Pada Tahap Perencanaan Obat di Puskesmas Karanganyar Kab. Demak pada Tahun 2017. Prosiding HEFA, 2(2): 251-257.

Athijah, U., Zairina, E., Sukorini, A. I. 2010. Perencanaan dan Pengadaan Obat di Puskesmas Surabaya Timur dan Selatan. Jurnal Farmasi Indonesia, 5(1): 15-23.

Hadidah, I. S. 2016. Analisa Kerugian Akibat Kejadian Obat Stagnant dan Stockout di Instalasi Farmasi: Studi di UPT Rumah Sakit Mata Masyarakat Jawa Timur. in: Skripsi. Surabaya: Universitas Airlangga.

Husnawati., Aryani, F., Juniati, A. 2016. Sistem Pengelolaan Obat di Puskesmas di Kecamatan Rambah Samo Kabupaten Rokan Hulu-Riau. Jurnal Pharmacy, 13(1): $1-13$.

Indriawan, I., Wahyudi, W. T., Rahayuningsih, A. 2014. Analisis Pengelolaan Obat di Puskesmas Gaya Baru V Kecamatan Bandar Surabaya Kabupaten Lampung Tengah. Jurnal Kesehatan Holistik, 8(1): 1-6.

Mangindara, Darmawansyah, Nurhayani, Balqis. 2012. Analisis Pengelolaan Obat di Puskesmas Kampala Kecamatan Sinjai Timur Kabupaten Sinjai Tahun 2011. Jurnal AKK, 1(1): $31-40$.

Muninjaya, A. 2004. Manajemen Kesehatan. Jakarta: EGC.

Notoatmodjo, S. 2012. Metodologi Penelitian Kesehatan. Jakarta: Rineka Cipta.

Oscar, L., Jauhar, M. 2016. Dasar-Dasar Manajemen Farmasi. Jakarta: Prestasi Pustaka.

Rahma, F. 2018. Perencanaan dan Pengadaan Obat di Puskesmas "X" Berdasarkan Permenkes Nomor 74 Tahun 2016. Jurnal Administrasi Kesehatan Indonesia, 6 (1): 15-20.

Riduan. 2015. Belajar Mudah Penelitian. Bandung: Alfabeta

Rismalawati, Lestari, H., Ahmad, L. O. A. I. 2015. Studi Manajemen Pengelolaan Obat di Puskesmas Lawa Kabupaten Muna Barat Tahun 2015. JIMKesmas. 1(3): $1-9$

Sudibyo, S. 2014. Metodologi Penelitian. Jakarta: Trans Info Media. 